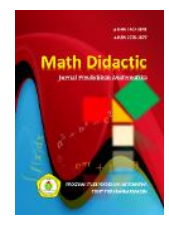

MATH DIDACTIC: JURNAL PENDIDIKAN MATEMATIKA

Volume 5 Nomor 1, Januari - April 2019, halaman 1 - 12

Tersedia Daring pada http://jurnal.stkipbjm.ac.id/index.php/math

\title{
PBL DENGAN PENDEKATAN REALISTIC MATHEMATIC MENINGKATKAN NILAI KARAKTER SISWA BERKEBUTUHAN KHUSUS
}

\section{PBL WITH A REALISTIC MATHEMATIC APPROACH IMPROVE THE VALUE OF CHARACTERS OF DIFABEL STUDENTS}

\author{
Sandha Soemantri \\ Universitas Muhammadiyah Surabaya \\ sandha.pendmat@fkip.um-surabaya.ac.id
}

\begin{abstract}
Abstrak: Pada 2010, pemerintah mendeklarasikan pendidikan budaya dan karakter bangsa yang kemudian dikaitkan dengan kondisi bangsa Indonesia yang menunjukkan perilaku antibudaya dan antikarakter. Perkembangan pendidikan karakter juga dirasakan oleh siswa berkebutuhan khusus. Mayoritas siswa di PKBM Imanuel Surabaya merupakan anak down syndrome dan slow learner yang mengakibatkan mereka sulit bersosialisasi dan memahami materi. Penelitian ini bertujuan untuk meningkatkan nilai karakter dan kemampuan matematika siswa berkebutuhan khusus. Beberapa prinsip dalam mendidik siswa berkebutuhan khusus adalah prinsip belajar kelompok, prinsip keterampilan, serta prinsip keperagaan, sehingga proses pembelajaran dalam penelitian ini menggunakan model pembelajaran Problem Based Learning (PBL) melalui pendekatan Realistic Mathematic Education (RME). Penelitian ini merupakan penelitian tindakan kelas melalui tahap Perencanaan, Pelaksanaan, Pengamatan, dan Refleksi. Hasil penelitian setelah siklus 2, aspek kemampuan matematika seluruh siswa mencapai nilai di atas standar ketuntasan yang ditetapkan, rata-rata tiap karakter nilai sudah mencapai nilai 3 (baik) dan rata-rata nilai karakter tiap individu juga telah melampaui nilai 3 (baik).
\end{abstract}

Kata Kunci: pendidikan karakter, siswa berkebutuhan khusus, penelitian tindakan kelas

\begin{abstract}
In 2010, the government declared the nation's cultural and character education which was later linked to the condition of the Indonesian nation which showed anti-cultural and anti-character behavior. The development of character education is also felt by difabel students. The majority of students in PKBM Imanuel Surabaya are children of down syndrome and slow learners which results in them having difficulty socializing and understanding the study material. This study aims to improve the character values and mathematical abilities of difabel students. Some principles in educating difabel students are the principle of group learning, the principles of skills, and the principle of adherence, so that the learning process in this study uses the Problem Based Learning (PBL) learning model through the Realistic Mathematic Education (RME) approach. This research is a classroom action research through the stages of Planning, Implementation, Observation, and Reflection. The results of the study after second cycle, the aspect of mathematical ability of all students reaches a value above the specified completeness standard, the average value of each character has reached a value of 3 and the average character value of each individual has also exceeded the value of 3 .
\end{abstract}

Keyword: character education, difabel student, classroom action research

Cara Sitasi: Soemantri, S. (2019). PBL dengan pendekatan realistic mathematic meningkatkan nilai karakter siswa berkebutuhan khusus. Math Didactic: Jurnal Pendidikan Matematika, 5(1), 1-12. https://doi.org/10.33654/math.v5i1.468. 
Pendidikan merupakan kebutuhan pokok bagi setiap insan. Indonesia mengatur pendidikan dalam Undang-undang Sistem Pendidikan Nasional No 20 Tahun 2003 pasal 1 ayat 1 yang berbunyi: Pendidikan adalah usaha sadar dan terencana untuk mewujudkan suasana belajar dan proses pembelajaran agar peserta didik secara aktif mengembangkan potensi dirinya untuk memiliki kekuatan spiritual keagamaan, pengendalian diri, kepribadian, kecerdasan, akhlak mulia, serta keterampilan yang diperlukan dirinya, masyarakat, bangsa dan negara. Pada bulan Januari 2010, Pemerintah mencanangkan pengembangan pendidikan karakter melalui "Deklarasi Pendidikan Budaya dan Karakter Bangsa". Hal ini ditegaskan dalam Pidato Presiden Susilo Bambang Yudhoyono pada peringatan Hari Pendidikan Nasional, 2 Mei 2010. Munculnya deklarasi ini dikaitkan dengan kondisi bangsa Indonesia yang menunjukkan perilaku antibudaya dan antikarakter (Marzuki, 2013). Secara etimologis, kata karakter berasal dari bahasa inggis, character, yang berarti watak atau sifat. Karakter merupakan nilai yang khas dari kepribadian seseorang yang terbentuk dari hasil internalisasi berbagai kebijakan yang dipergunakan untuk bertingkah laku dalam kehidupan sehari-hari (Koesoema, 2007).

Pemerintah menjabarkan nilai pendidikan karakter dalam 18 nilai, yaitu religius, jujur, toleransi, disiplin, kerja keras, kreatif, mandiri, demokratis, rasa ingin tahu, semangat kebangsaan, cinta tanah air, menghargai prestasi, bersahabat/komunikatif, cinta damai, gemar membaca, peduli lingkungan, peduli sosial dan tanggung jawab (Zuhdi, dkk, 2011). Perkembangan pendidikan karakter ini juga dirasakan oleh siswa berkebutuhan khusus, karena pada dasarnya siswa berkebutuhan khusus sama seperti siswa lain yang membutuhkan perhatian dan pendidikan yang layak. Secara tersirat, istilah berkebutuhan khusus ditujukan kepada anak yang memiliki kelainan/penyimpangan dari kondisi rata-rata anak normal umumnya, dalam hal fisik, mental maupun karakteristik perilaku sosialnya (Efendi, 2006).

Selama ini, anak berkebutuhan khusus dianggap sebagai siswa yang lamban dalam proses belajar, padahal ada juga anak yang sangat cepat dalam menyerap ilmu yang diberikan guru. Siswa berkebutuhan khusus bukan semata siswa yang memiliki kekurangan fisik, tetapi bisa juga mengalami disleksia (kesulitan membaca dan menulis), susah berkonsentrasi dan hiperaktif. Hal ini juga terjadi pada siswa kelas IX di PKBM Imanuel Surabaya. Mayoritas siswa kelas IX di PKBM Imanuel Surabaya merupakan anak down syndrome dan slow learner. Hal ini mengakibatkan sulitnya mereka untuk bersosialisasi dan memahami materi.

Menurut buku pedoman Penyelenggaraan Inklusi Direktorat PSLB (2004), program pembelajaran yang disusun oleh guru untuk kelas inklusi sama dengan program pembelajaran pada kelas reguler. Tetapi, kebutuhan dalam kurikulum reguler harus diadaptasi dan dimodifikasi sehingga sesuai dengan kebutuhan siswa berkebutuhan khusus.

Modifikasi kurikulum dilakukan guru pada strategi pembelajaran, jenis penilaian, maupun pada program tambahan lainnya dengan tetap mengacu pada kebutuhan siswa.

Menurut buku pedoman Penyelenggaraan Inklusi Direktorat PSLB (2004), penekanan ada pada taraf kesulitan materi yang disusun dari yang konkret menuju abstrak, dari yang mudah menuju sulit, dan dari sederhana menuju yang kompleks. Oleh karena itu, metode apapun dapat digunakan guru untuk 
menyampaikan materi dan meningkatkan karakter siswa berkebutuhan khusus.

Selama ini, guru kelas IX PKBM Imanuel Surabaya menerapkan strategi pembelajaran konvensional melalui metode ceramah, tanya jawab dan penugasan. Dari strategi tersebut, karakter dan kemampuan matematika siswa relatif rendah. Pada gambar 1 dan 2 disajikan hasil rekapitulasi nilai karakter dan kemampuan matematika siswa kelas IX PKBM Imanuel Surabaya selama bulan Januari 2018.

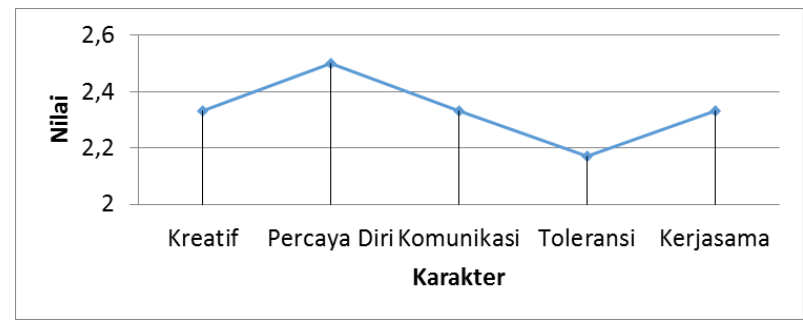

Gambar 1. Nilai karakter siswa PKBM Imanuel Surabaya

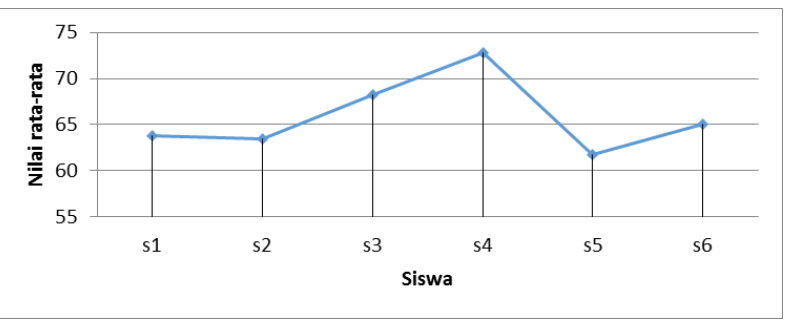

Gambar 2. Kemampuan matematika siswa PKBM Imanuel Surabaya

Dari gambar 1 terlihat bahwa dengan menggunakan model pembelajaran konvensional siswa kelas IX PKBM Imanuel Surabaya belum mencapai target karakter yang diinginkan yaitu 3, terutama pada kreatif, percaya diri, komunikasi, toleransi, dan kerjasama. Pengambilan nilai 3 sebagai nilai minimal dikarenakan penggunaan lembar observasi dengan skala $1-4$ dengan keterangan 1 tidak baik, 2 kurang baik, 3 baik, dan 4 sangat baik. Gambar 2 juga menunjukkan bahwa nilai matematika siswa selama bulan Januari 2018 juga masih jauh dari nilai standar ketuntasan minimal yang ditetapkan yaitu 75 .

Menurut Abdullah (2013), beberapa prinsip-prinsip pendekatan secara khusus, yang dapat dijadikan dasar dalam upaya mendidik anak berkebutuhan khusus antara lain sebagai berikut:

1. Prinsip kasih sayang. Pada dasarnya adalah menerima mereka apa adanya. upaya yang dilakukan antara lain tidak bersikap memanjakan, tidak bersikap acuh tak acuh, dan memberikan tugas yang sesuai dengan kemampuan anak.

2. Prinsip layanan individual. Upaya yang perlu dilakukan antara lain jumlah siswa yang dilayani antara $4-6$ siswa per kelas, kurikulum dan jadwal pelajaran dapat bersifat fleksibel, tata ruang harus dirancang sedemikian rupa sehingga guru dapat menjangkau semua siswa dengan mudah, dan adanya alat bantu pembelajaran.

3. Prinsip kesiapan. Untuk menerima suatu pelajaran tertentu diperlukan kesiapan khususnya kesiapan dalam pengetahuan prasyarat, baik pengetahuan, mental, serta fisik

4. Prinsip keperagaan. Alat peraga yang digunakan untuk media sebaiknya diupayakan menggunakan benda nyata atau yang sesuai dengan situasi aslinya.

5. Prinsip motivasi. Pada dasarnya prinsip motivasi lebih menitikberatkan pada cara mengajar dan pemberian evaluasi yang disesuaikan dengan kondisi anak

6. Prinsip belajar dan bekerja kelompok. Titik berat dalam hal ini adalah kemampuan anak untuk belajar dan bekerja secara berkelompok, sehingga nantinya dapat bergaul dengan masyarakat di lingkungannya, tanpa harus merasa rendah diri. 
7. Prinsip keterampilan. Titik berat pada prinsip ini adalah keterampilan yang berfungsi selektif, edukatif, rekreatif dan terapi, serta dapat dijadikan sebagai bekal dalam kehidupannya kelak.

8. Prinsip penanaman dan penyempurnaan sikap, yang mengharapakan bahwa anak berkebutuhan khusus memiliki sikap yang baik sehingga tidak selalu menjadi perhatian orang lain.

$\begin{array}{ccc}\text { Dari beberapa latar } & \text { belakang } \\ \text { permasalahan tersebut, } & \text { maka } & \text { strategi }\end{array}$ pembelajaran yang semula bersifat teacher center harus diubah menjadi student center. Selain itu, diupayakan untuk meningkatkan kemampuan sosial dan kognitif, sehingga harus diterapkan strategi pembelajaran secara kooperatif dengan kegiatan praktik nyata. Strategi yang digunakan pada penelitian ini adalah penggunaan model pembelajaran Problem Based Learning (PBL) melalui pendekatan Realistic Mathematic.

Pemilihan Model Problem Based Learning dikarenakan beberapa pendapat ahli beserta hasil penelitian yang telah dilakukan. Mayoritas beranggapan bahwa Problem Based Learning mampu meningkatkan nilai karakter berupa kreatif, percaya diri, komunikasi, toleransi, dan kerjasama. Stepien dan Gallagher (1993) menyatakan model Problem Based Learning mampu mengubah instruksi menjadi "kacau balau". Siswa akan dihadapkan dengan "masalah yang tidak terstruktur" sehingga siswa akan menyelidiki masalah secara mendalam dengan mencari koneksi, bergulat dengan kompleksitas, dan menggunakan pengetahuan untuk mencapai solusi. Dalam hal ini, motivasi siswa akan meningkat, karena siswa menyadari bahwa itu adalah masalah mereka. Dengan kesadaran yang dimiliki, siswa juga akan menginterpretasikan masalah dan menyelesaikannya melalui cara kreatif.

Senada dengan pendapat Stepien dan Gallagher, Barrows (dalam Hmelo-Silver dan Barrows, 2006) menjelaskan bahwa Problem Based Learning adalah metode pembelajaran aktif yang didasarkan pada penggunaan masalah yang tidak terstruktur sebagai stimulus untuk belajar sehingga tidak dapat diselesaikan dengan algoritma sederhana. Masalah semacam itu tidak selalu memiliki jawaban yang benar tetapi mengharuskan siswa untuk memunculkan alternatif penyelesaian dan memberikan argumen untuk mendukung solusi yang mereka hasilkan. Dalam Problem Based Learning, siswa memiliki kesempatan untuk mengembangkan keterampilan dalam penalaran dan belajar mandiri. Studi empiris Problem Based Learning telah menunjukkan bahwa siswa yang telah belajar dari kurikulum PBL lebih mampu menerapkan pengetahuan mereka untuk masalah baru secara percaya diri.

Salah satu prinsip pendekatan untuk mendidik anak berkebutuhan khusus adalah prinsip keperagaan, sehingga sebaiknya siswa diajak mengalami hal nyata atau seperti nyata. Proses pembelajaran dalam penelitian ini akan menggunakan pendekatan nyata melalui Realistic Mathematic Education (RME). Seni pembelajaran menurut RME adalah memberi siswa kesempatan untuk memproduksi hal-hal yang lebih konkret dan mengkreasi pengetahuan sendiri sebagai titik awal untuk memahami konsep matematika dan formalisasi bertahap dari strategi informal. (de Lange dalam Widjaja dan Heck. 2003). Jadi, dalam proses pembelajaran, siswa didorong untuk menyadari dan mengidentifikasi aspek-aspek matematika dalam kehidupan sehari-hari yang dialami dengan kemudian memberi makna dari masalah pada dunia nyata. Mereka ditantang 
untuk mengembangkan strategi dan pendekatan mereka sendiri untuk memecahkan masalah dan mendiskusikannya dengan teman sebaya. Peran guru adalah sebagai fasilitator dalam proses refleksi saat diskusi.

Dari latar belakang yang muncul dan beberapa pendapat ahli yang mendukung, peneliti melaksanakan penelitian dengan judul meningkatkan nilai karakter siswa berkebutuhan khusus melalui model problem based learning dengan pendekatan realistic mathematic pada siswa kelas IX PKBM Imanuel Surabaya.

\section{Metode Penelitian}

Penelitian ini dilakukan pada bulan Januari - Februari 2018 di kelas IX PKBM Imanuel Surabaya yang dipilih berdasarkan hasil pengamatan kelas dan wawancara dengan guru kelas tersebut dengan subjek semua siswa kelas IX yang terdiri dari 3 orang perempuan dan 3 orang laki-laki.

Teknik pengumpulan data yang digunakan dalam penelitian ini adalah tes dan lembar pengamatan. Tes diberikan kepada siswa untuk mendapatkan nilai matematika siswa. Lembar pengamatan digunakan untuk mencatat informasi dari semua kegiatan yang sedang berlangsung. Lembar pengamatan yang digunakan berupa lembar pengamatan nilai karakter siswa yang digunakan saat berlangsungnya proses pembelajaran.

Data yang diperoleh dalam setiap tindakan akan dianalisis secara kuantitatif untuk mengetahui hasil akhir dari suatu tindakan. Nilai karakter siswa dalam lembar pengamatan terdiri dari 4 nilai yaitu Sangat Tidak Baik (nilai 1), Tidak Baik (nilai 2), Baik (nilai 1), dan Sangat Baik (nilai 4). Dari nilai yang diperoleh saat pengamatan, akan dicari nilai rata-ratanya yang kemudian digunakan sebagai nilai per indikator karakter. Perhitungan nilai rata-rata juga digunakan pada nilai kemampuan matematika siswa melalui evaluasi tiap akhir minggu.

Penelitian ini dilakukan dengan menggunakan metode penelitian tindakan kelas (PTK). Ada empat tahapan yang dilakukan dalam penelitian tindakan kelas, yaitu (1) Perencanaan, (2) Pelaksanaan, (3) Pengamatan, dan (4) Refleksi (Arikunto, 2006). Lebih jelas dapat dilihat pada gambar 3 di bawah ini:

\begin{tabular}{|c|c|c|c|}
\hline Perencanaan & Pelaksanaan & Pengamatan & Refleksi \\
\hline \multicolumn{4}{|l|}{ SIKLUS I } \\
\hline$\downarrow$ & & & \\
\hline Perencanaan & Pelaksanaan & Pengamatan & Refleksi \\
\hline
\end{tabular}

Gambar 3. Alur Penelitian Tindakan Kelas

Keempat langkah di atas dilakukan untuk meningkatkan nilai karakter serta kemampuan matematika siswa. Secara jelas keempat langkah di atas dipaparkan sebagai berikut.

\section{Perencanaan}

Pada tahap ini, peneliti menyusun dan merancang tindakan yang akan dilaksanakan untuk meningkatkan nilai karakter serta kemampuan matematika siswa. Berdasarkan tes awal dan pengamatan yang dilakukan, nilai karakter yang diperoleh adalah Kreatif 2.33, Percaya Diri 2.5, Komunikasi 2.33, Toleransi 2.17, dan Kerjasama 2.33. Sedangkan nilai rata-rata kemampuan siswa hanya 65.8. Rencana tindakan yang dilaksanakan dalam tahapan ini adalah menggunakan model Problem Based Learning dengan pendekatan realistic mathematic.

\section{Pelaksanaan}

Pada tahap ini peneliti menerapkan langkah-langkah pembelajaran dengan model Problem Based Learning dengan pendekatan realistic mathematic sesuai 
dengan rancangan pembelajaran yang telah dipersiapkan pada tahap pertama. Dalam penerapannya, peneliti melaksanakan kegiatan pembelajaran sesuai dengan rancangan pembelajaran yang telah disusun.

Langkah pertama berupa orientasi siswa pada masalah. Guru menjelaskan tujuan pembelajaran agar siswa dapat menentukan dan menyelesaikan masalah kontekstual yang berkaitan dengan nilai mean, median, dan modus. Guru menyampaikan bahwa pembelajaran akan dilakukan secara berkelompok menggunakan alat dan bahan berupa timbangan dan meteran. Selanjutnya siswa diberi motivasi dengan mengucapkan katakata "Saya bisa dan saya pasti bisa".

Langkah kedua adalah mengorganisasi siswa untuk belajar. siswa dibagi menjadi 3 kelompok dengan masingmasing kelompok beranggotakan 2 orang. Tiap kelompok mendapat LKS yang berbeda dari guru. Masalah yang diberikan pada LKS berkaitan dengan bagaimana menentukan konsep mencari nilai rata-rata, modus, dan median melalui kegiatan nyata dari data ukuran sepatu, tinggi badan, dan berat badan teman sekelas.

Langkah ketiga adalah membimbing pengalaman individual atau kelompok. Guru berkeliling untuk mengecek proses diskusi kelompok dan bertanya pada setiap kelompok tentang masalah tersebut. Siswa diberi motivasi agar mampu menalar dan menyelesaikan masalah secara mandiri.

Langkah keempat adalah mengembangkan dan menyajikan hasil karya. Hasil diskusi kelompok yang diperoleh dari pengolahan data tersebut dipresentasikan di depan kelas secara bergantian, sedangkan kelompok lain memberi tanggapan dan pertanyaan dengan guru sebagai fasilitator.

Langkah kelima, menganalisis dan mengevaluasi proses pemecahan masalah. Siswa diarahkan atau difasilitasi oleh guru agar bertanya tentang hal-hal yang belum dipahami. Guru memberikan penjelasan tambahan apabila ada siswa yang bertanya. Guru bersama siswa mengambil kesimpulan dalam kegiatan pembelajaran tersebut. Guru memberikan apresiasi kepada setiap kelompok atas kerja tim nya. Apresiasi berupa penghargaan sederhana yang diharapkan mampu meningkatkan motovasi belajar siswa. Pada pertemuan berikutnya, siswa mengerjakan soal evaluasi yang diberikan guru untuk mengetahui tingkat pemahaman siswa terkait materi yang telah dipelajari bersama.

\section{Pengamatan}

Peneliti mengamati karakter yang dimunculkan oleh tindakan siswa saat pembelajaran berlangsung. Pengumpulan data dilakukan dengan menggunakan tes dan lembar pengamatan yang telah disusun sebelumnya. Data yang dikumpulkan adalah dalam bentuk data kuantitatif dari hasil tes siswa dan lembar pengamatan. Hal-hal lain yang penting yang berhubungan dengan tindakan juga dicatat oleh peneliti. Lembar pengamatan karakter yang disusun, ditunjukkan pada tabel 1.

Tabel 1. Lembar Pengamatan Karakter Siswa

\begin{tabular}{|c|c|c|c|c|c|}
\hline $\begin{array}{c}\text { Kegiatan } \\
\text { Siswa }\end{array}$ & Karakter & $\begin{array}{c}\text { STB } \\
\text { (1) }\end{array}$ & $\begin{array}{c}\text { TB } \\
\text { (2) }\end{array}$ & $\begin{array}{c}\text { B } \\
\text { (3) }\end{array}$ & $\begin{array}{c}\text { SB } \\
\text { (4) }\end{array}$ \\
\hline $\begin{array}{c}\text { Bersedia } \\
\text { memimpin doa } \\
\text { di depan kelas }\end{array}$ & $\begin{array}{c}\text { Percaya } \\
\text { Diri }\end{array}$ & & & & \\
\hline $\begin{array}{c}\text { Mengucapkan } \\
\text { kata motivasi } \\
\text { dengan penuh } \\
\text { semangat }\end{array}$ & $\begin{array}{c}\text { Percaya } \\
\text { Diri }\end{array}$ & & & & \\
\hline $\begin{array}{c}\text { Bersedia } \\
\text { berkelompok }\end{array}$ & Toleransi & & & & \\
\hline
\end{tabular}




\begin{tabular}{|c|c|c|c|c|c|}
\hline $\begin{array}{l}\text { Kegiatan } \\
\text { Siswa }\end{array}$ & Karakter & $\begin{array}{c}\text { STB } \\
\text { (1) }\end{array}$ & $\begin{array}{l}\text { TB } \\
(2)\end{array}$ & $\begin{array}{c}\text { B } \\
(3)\end{array}$ & $\begin{array}{l}\text { SB } \\
\text { (4) }\end{array}$ \\
\hline \multicolumn{6}{|l|}{$\begin{array}{c}\text { dengan siapa } \\
\text { saja }\end{array}$} \\
\hline \multirow{4}{*}{$\begin{array}{l}\text { Aktif dalam } \\
\text { kegiatan } \\
\text { pengumpulan } \\
\text { data dan } \\
\text { diskusi }\end{array}$} & Kreatif & & & & \\
\hline & Komunikasi & & & & \\
\hline & Kerjasama & & & & \\
\hline & Toleransi & & & & \\
\hline $\begin{array}{c}\text { Presentasi hasil } \\
\text { diskusi di } \\
\text { depan kelas }\end{array}$ & $\begin{array}{c}\text { Percaya } \\
\text { Diri }\end{array}$ & & & & \\
\hline $\begin{array}{c}\text { Memperhatikan } \\
\text { kelompok lain } \\
\text { presentasi }\end{array}$ & Toleransi & & & & \\
\hline \multirow{2}{*}{$\begin{array}{l}\text { Bertanya pada } \\
\text { teman yang } \\
\text { telah presentasi }\end{array}$} & $\begin{array}{c}\text { Percaya } \\
\text { Diri }\end{array}$ & & & & \\
\hline & Komunikasi & & & & \\
\hline \multirow{2}{*}{$\begin{array}{c}\text { Berani } \\
\text { menyampaikan } \\
\text { pendapat saat } \\
\text { kegiatan } \\
\text { refleksi }\end{array}$} & $\begin{array}{c}\text { Percaya } \\
\text { Diri }\end{array}$ & & & & \\
\hline & Komunikasi & & & & \\
\hline
\end{tabular}

\section{Refleksi}

Tahap ini dilakukan untuk mengkaji seluruh tindakan yang telah dilakukan berdasar data yang terkumpul pada tahaptahap sebelumnya serta mencari kesulitan yang dialami oleh siswa dan guru dalam proses tindakan yang telah dilakukan. Siswa diajak diskusi pada setiap siklus untuk menanyakan kesulitan-kesulitan yang mereka rasakan, sedangkan guru merenungkan kembali kegiatan yang telah dilaksanakan. Semua data yang diperoleh dianalisis dan dievaluasi untuk menyempurnakan tindakan pada siklus berikutnya atau perlu tidaknya perlakuan yang diberikan kepada siswa untuk dilanjutkan.

\section{Hasil dan Pembahasan}

Menurut Arikunto, Suhardjono, dan Supardi (2006), dalam penyampaian hasil penelitian dan pembahasan, sebaiknya disajikan uraian masing-masing siklus dengan data lengkap mulai tahap perencanaan, pelaksanaan, pengamatan, hingga tahapan refleksi dengan menjelaskan aspek keberhasilan dan kelemahan yang ada. Hal ini juga didukung dengan menampilkan grafik dan tabel agar perubahan yang terjadi terlihat sistematis dan jelas. Bentuk pelaksanaan tahap-tahap dalam siklus 1 dijabarkan sebagai berikut.

\section{Siklus 1}

\section{Tahap Perencanaan Siklus 1}

Hasil yang didapat dari kegiatan perencanaan meliputi:

a. Menyusun Rencana Pelaksanaan Pembelajaran (RPP) yang menggunakan langkah-langkah dalam model Problem Based Learning (PBL) dan Realistic Mathematic serta disesuaikan dengan kemampuan siswa kelas IX PKBM Imanuel Surabaya. Rencana pembelajaran yang disusun juga memperhatikan buku pedoman Penyelenggaraan Inklusi Direktorat PSLB (2004) tentang tingkat abstraksi dan kemampuan siswa.

b. Menentukan waktu pelaksanaan tindakan berupa hari dan tanggal yang disesuaikan dengan materi pembelajaran matematika bab Statistika. Hasil kesepakatan dengan guru kelas adalah 19 dan 21 Februari 2018.

c. Menyusun format lembar pengamatan yang sesuai dengan peningkatan karakter yang diharapkan.

d. Peneliti meminta kepada guru kelas agar memberikan penjelasan pada siswa bahwa kehadiran peneliti ke kelas bukan untuk menilai kesalahan atau kelemahan dalam pembelajaran.

e. Merencanakan bahan pelajaran dan merumuskan tujuan pembelajaran. 
f. Memilih dan mengorganisasikan materi, media, dan sumber belajar yang sesuai dengan tujuan penelitian.

\section{Tahap Pelaksanaan Siklus 1}

Pada tahap ini, guru secara umum telah melakukan pengelolaan kelas dengan baik. Proses pembelajaran dilaksanakan dengan langkah-langkah yang benar sesuai model Problem Based Learning (PBL) dengan pendekatan Realistic Mathematic. Secara rinci dijelaskan sebagai berikut.

Langkah pertama guru menjelaskan tujuan pembelajaran bahwa pembelajaran akan dilakukan secara berkelompok menggunakan alat dan bahan berupa timbangan dan meteran untuk menentukan aturan mean, median, dan modus. Langkah berikutnya, siswa dibagi menjadi 3 kelompok dengan masing-masing kelompok beranggotakan 2 orang. Tiap kelompok mendapat LKS dengan berisi masalah yang berkaitan dengan bagaimana menentukan konsep mencari nilai rata-rata, modus, dan median melalui kegiatan nyata dari data ukuran sepatu, tinggi badan, dan berat badan teman sekelas. Kegiatan nyata dalam penanaman konsep tersebut ditunjukkan oleh gambar 4.
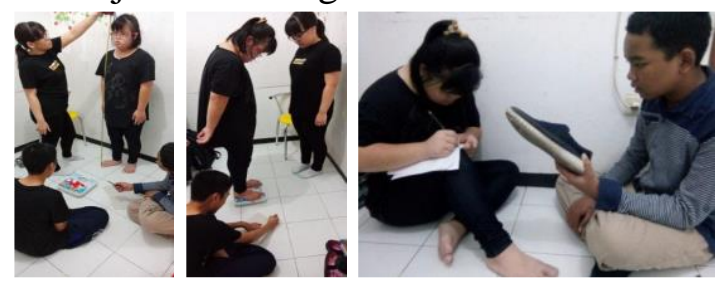

Gambar 4. Aktivitas pengumpulan data secara nyata

Langkah ketiga, guru sebagai fasilitator berkeliling untuk mengecek proses diskusi kelompok dan bertanya pada setiap kelompok tentang masalah tersebut. Dalam kegiatan ini, siswa dimotivasi agar mampu berkreasi, menalar dan menyelesaikan masalah secara bersamasama. Langkah selanjutnya, setiap kelompok diminta mempresentasikan hasil diskusinya di depan kelas secara bergantian. Dalam kegiatan ini, kelompok lain diminta memberi tanggapan dan pertanyaan kepada kelompok yang presentasi.

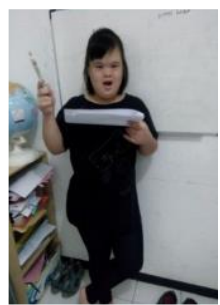

Gambar 5. Kegiatan presentasi hasil diskusi

Langkah terakhir, siswa diberi kesempatan untuk menanyakan hal-hal yang belum dipahami. Kemudian, siswa diajak untuk membuat kesimpulan setelah mengalami kegiatan pembelajaran. Guru memberikan apresiasi kepada setiap kelompok atas kerja tim nya. Pada pertemuan berikutnya, siswa diminta mengerjakan soal evaluasi untuk mengetahui tingkat pemahaman siswa.

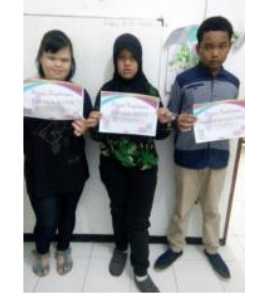

Gambar 6. Pemberian apresiasi kepada semua kelompok

\section{Tahap Pengamatan Siklus 1}

Pada tahap ini, peneliti mengamati karakter yang ditunjukkan melalui tindakan siswa saat berlangsungnya proses belajar. Pengumpulan data dilakukan menggunakan lembar pengamatan yang telah disusun sebelumnya. Hasil yang diperoleh ditunjukkan pada tabel 2. 
Tabel 2. Hasil pengamatan tingkat karakter siswa

\begin{tabular}{|c|c|c|c|c|c|c|c|}
\hline $\begin{array}{c}\text { Subjek } \\
\text { Karakter }\end{array}$ & S1 & S2 & S3 & S4 & S5 & S6 & $\begin{array}{c}\text { Rata- } \\
\text { Rata }\end{array}$ \\
\hline Percaya Diri & 3.0 & 3.2 & 3.4 & 2.8 & 3.2 & 3.0 & 3.1 \\
\hline Toleransi & 3.3 & 3.0 & 3.3 & 3.7 & 3.3 & 3.0 & 3.3 \\
\hline Kreatif & 3.0 & 3.0 & 2.0 & 4.0 & 4.0 & 3.0 & 3.2 \\
\hline Komunikasi & 3.0 & 3.0 & 3.7 & 3.0 & 2.7 & 3.7 & 3.2 \\
\hline Kerjasama & 3.0 & 3.0 & 2.0 & 3.0 & 4.0 & 4.0 & 3.2 \\
\hline Rata-Rata & $\mathbf{3 . 1}$ & $\mathbf{3 . 0}$ & $\mathbf{2 . 9}$ & $\mathbf{3 . 3}$ & $\mathbf{3 . 4}$ & $\mathbf{3 . 3}$ & \\
\hline
\end{tabular}

\section{Refleksi Siklus 1}

Refleksi siklus 1 mengkaji seluruh tindakan yang telah dilakukan berdasarkan data yang telah terkumpul. Berikut hasil analisis data yang diperoleh.

a. Kemampuan matematika siswa

Tabel 3. Hasil belajar siswa siklus 1

\begin{tabular}{|c|c|c|}
\hline Subjek & Nilai Tes & Keterangan \\
\hline S1 & 72 & Tidak Lulus \\
\hline S2 & 68 & Tidak Lulus \\
\hline S3 & 76 & Lulus \\
\hline S4 & 72 & Tidak Lulus \\
\hline S5 & 60 & Tidak Lulus \\
\hline S6 & 70 & Tidak Lulus \\
\hline Rata-Rata & $\mathbf{6 9 . 7}$ & \\
\hline
\end{tabular}

Berdasarkan data yang ditunjukkan pada tabel 3, terlihat bahwa rata-rata nilai yang diperoleh siswa kelas IX PKBM Imanuel Surabaya adalah 69,7. Nilai ini masih belum mencapai standar ketuntasan minimal PKBM sebesar 75. Hal ini dimungkinkan karena penguasaan konsep yang diperoleh siswa masih prematur.

b. Nilai karakter siswa

Berdasarkan data yang ditunjukkan pada tabel 2, nilai karakter siswa relatif meningkat dibandingkan sebelumnya (data pada gambar 1). Ratarata tiap karakter nilai sudah mencapai nilai 3 dengan rincian percaya diri 3.1, toleransi 3.3, kreatif 3.2, komunikasi 3.2, dan kerjasama 3.2. Namun rata-rata nilai karakter individu masih ada yang belum mencapai nilai 3 yaitu 2.9.

c. Simpulan refleksi

Perlu diingat bahwa indikator keberhasilan pada penelitian ini adalah saat hasil belajar siswa telah mencapai standar ketuntasan minimal sebesar 75 serta nilai karakter mencapai nilai 3 . Ternyata dalam siklus 1, hasil belajar matematika siswa masih berada pada nilai 69,7 dan ada individu dengan ratarata nilai karakter 2,9. Oleh karena itu, penelitian ini harus dilanjutkan ke siklus 2.

\section{SIKLUS 2}

Proses siklus 2 hampir sama dengan siklus 1, namun ada sedikit perubahan pada tahap pelaksanaan dimana siswa diberi kesempatan lebih banyak untuk mengekspresikan diri. Untuk lebih jelas dijabarkan sebagai berikut.

\section{Tahap Perencanaan Siklus 2}

a. Menyusun Rencana Pelaksanaan Pembelajaran (RPP) yang sesuai.

b. Menentukan waktu pelaksanaan tindakan berupa hari dan tanggal yang disesuaikan dengan pertemuan lanjutan yaitu 26 dan 28 Februari 2018.

c. Merencanakan bahan pelajaran dan merumuskan tujuan pembelajaran.

d. Memilih dan mengorganisasikan materi, media, dan sumber belajar yang sesuai dengan tujuan penelitian.

\section{Tahap Pelaksanaan Siklus 2}

Sama dengan pelaksanaan saat siklus 1, guru mengelola kelas dengan sangat baik melalui penerapan model Problem Based Learning (PBL) dengan pendekatan 
Realistic Mathematic. Secara rinci dijelaskan sebagai berikut.

Langkah pertama guru menjelaskan tujuan pembelajaran bahwa pembelajaran akan dilakukan secara berkelompok seperti minggu sebelumnya yaitu menggunakan alat dan bahan berupa timbangan dan meteran untuk menguatkan konsep mean, median, dan modus. Langkah kedua, siswa dibagi menjadi 3 kelompok dengan masingmasing kelompok beranggotakan 2 orang namun kelompok yang dibentuk akan berbeda dengan pertemuan sebelumnya. Tiap kelompok mendapat LKS dengan berisi masalah yang berkaitan dengan bagaimana menentukan konsep mencari nilai rata-rata, modus, dan median melalui kegiatan nyata dari data ukuran panjang jengkal, panjang kotak pensil, dan berat tas teman sekelas.

Langkah berikutnya, guru sebagai fasilitator berkeliling untuk mengecek proses diskusi kelompok dan mengajukan pertanyaan pada tiap kelompok tentang masalah yang dihadapi. Dalam kegiatan ini, guru memberi motivasi lebih serta mengajak siswa untuk lebih berani mengutarakan pendapat, berkreasi, menalar dan menyelesaikan masalah secara berkelompok. Langkah keempat, setiap kelompok diminta mempresentasikan hasil diskusinya di depan kelas secara bergantian. Pada tahap ini, setiap siswa dari kelompok lain diminta memberi tanggapan dan pertanyaan kepada kelompok yang presentasi dengan harapan seluruh siswa lebih percaya diri dan terampil dalam komunikasi.

Langkah kelima, siswa diajak untuk membuat kesimpulan setelah mengalami kegiatan pembelajaran. Guru memberikan apresiasi kepada setiap kelompok atas kerja tim nya. Pada pertemuan berikutnya, siswa diminta mengerjakan soal evaluasi untuk mengetahui tingkat pemahaman siswa.

\section{Tahap Pengamatan Siklus 2}

Pada tahap ini, peneliti mengamati karakter yang ditunjukkan melalui tindakan siswa saat berlangsungnya proses belajar. Pengumpulan data dilakukan menggunakan lembar pengamatan yang telah disusun sebelumnya. Hasil yang diperoleh ditunjukkan pada tabel 4.

Tabel 4. Hasil pengamatan tingkat karakter siswa

\begin{tabular}{|c|c|c|c|c|c|c|c|}
\hline $\begin{array}{l}\text { Subjek } \\
\text { Karakter }\end{array}$ & S1 & S2 & S3 & S4 & S5 & S6 & $\begin{array}{c}\text { Rata } \\
\text { - } \\
\text { Rata }\end{array}$ \\
\hline $\begin{array}{c}\text { Percaya } \\
\text { Diri }\end{array}$ & $\begin{array}{l}3 . \\
0\end{array}$ & $\begin{array}{l}3 . \\
6\end{array}$ & $\begin{array}{l}3 . \\
4\end{array}$ & $\begin{array}{l}3 . \\
0\end{array}$ & $\begin{array}{l}3 . \\
4\end{array}$ & $\begin{array}{l}3 . \\
4\end{array}$ & 3.3 \\
\hline Toleransi & $\begin{array}{l}3 . \\
7\end{array}$ & $\begin{array}{l}3 . \\
3\end{array}$ & $\begin{array}{l}3 . \\
3\end{array}$ & $\begin{array}{l}3 . \\
7\end{array}$ & $\begin{array}{l}3 . \\
7\end{array}$ & $\begin{array}{l}3 . \\
7\end{array}$ & 3.6 \\
\hline Kreatif & $\begin{array}{l}3 . \\
0\end{array}$ & $\begin{array}{c}4 . \\
0\end{array}$ & $\begin{array}{l}3 . \\
0\end{array}$ & $\begin{array}{c}4 . \\
0\end{array}$ & $\begin{array}{r}4 . \\
0\end{array}$ & $\begin{array}{r}4 . \\
0\end{array}$ & 3.7 \\
\hline $\begin{array}{l}\text { Komunika } \\
\text { si }\end{array}$ & $\begin{array}{l}3 . \\
0\end{array}$ & $\begin{array}{l}3 . \\
7\end{array}$ & $\begin{array}{l}3 . \\
7\end{array}$ & $\begin{array}{l}3 . \\
7\end{array}$ & $\begin{array}{l}3 . \\
0\end{array}$ & $\begin{array}{r}4 . \\
0\end{array}$ & 3.5 \\
\hline Kerjasama & $\begin{array}{c}4 . \\
0\end{array}$ & $\begin{array}{c}4 . \\
0\end{array}$ & $\begin{array}{l}3 . \\
0\end{array}$ & $\begin{array}{l}3 . \\
0\end{array}$ & $\begin{array}{r}4 . \\
0\end{array}$ & $\begin{array}{r}4 . \\
0\end{array}$ & 3.7 \\
\hline Rata-Rata & $\begin{array}{l}3 . \\
3\end{array}$ & $\begin{array}{l}3 . \\
7\end{array}$ & $\begin{array}{l}3 . \\
3\end{array}$ & $\begin{array}{l}3 . \\
5\end{array}$ & $\begin{array}{l}3 . \\
6\end{array}$ & $\begin{array}{l}3 . \\
8\end{array}$ & \\
\hline
\end{tabular}

\section{Refleksi Siklus 2}

Refleksi siklus 2 mengkaji seluruh tindakan yang telah dilakukan berdasarkan data yang telah terkumpul. Berikut hasil analisis data yang diperoleh.

a. Kemampuan matematika siswa

Tabel 5. Hasil belajar siswa siklus 2

\begin{tabular}{|c|c|c|}
\hline Subjek & Nilai Tes & Keterangan \\
\hline S1 & 82 & Lulus \\
\hline S2 & 78 & Lulus \\
\hline S3 & 80 & Lulus \\
\hline S4 & 82 & Lulus \\
\hline S5 & 76 & Lulus \\
\hline S6 & 86 & Lulus \\
\hline Rata-Rata & $\mathbf{8 0 . 7}$ & \\
\hline
\end{tabular}

Berdasarkan data yang ditunjukkan pada tabel 5 , terlihat bahwa 
rata-rata nilai yang diperoleh siswa kelas IX PKBM Imanuel Surabaya telah mencapai 80,7. Nilai siswa mengalami peningkatan yang signifikan dikarenakan penguasaan konsep telah tertanam dengan baik.

b. Nilai karakter siswa

Berdasarkan data yang ditunjukkan pada tabel 4, nilai karakter siswa telah meningkat tajam dibandingkan data pada siklus 1 (tabel 2). Rata-rata tiap karakter nilai sudah mencapai nilai 3 dengan rincian percaya diri 3.3, toleransi 3.6, kreatif 3.7, komunikasi 3.5, dan kerjasama 3.7. Ratarata nilai karakter tiap individu juga telah melampaui nilai 3 .

\section{c. Simpulan refleksi}

Hasil analisis data hasil belajar siswa siklus 2 telah melampaui standar ketuntasan minimal sebesar 75 serta nilai rata-rata tiap karakter dan rata-rata nilai karakter individu melampaui nilai 3 . Dengan nilai tersebut, maka penelitian tindakan kelas ini tidak perlu dilanjutkan ke siklus berikutnya.

\section{Simpulan}

Karakter siswa berkebutuhan khusus memang unik. Dari pengamatan di PKBM Imanuel Surabaya, terlihat bahwa siswa kelas IX cenderung individualis dan kurang sosialisasi. Hal ini juga ditunjang oleh model pembelajaran secara konvensional. Oleh karena itu, peneliti menerapkan sebuah model pembelajaran untuk meningkatkan karakter siswa yang sekaligus meningkatkan kemampuan matematika siswa melalui proses belajar yang menarik dan dialami langsung oleh siswa melalui model Problem Based Learning (PBL) dengan pendekatan Realistic Mathematic.

Dari hasil penelitian yang disampaikan di sub bab sebelumnya dengan dukungan data yang ada, tujuan penelitian tindakan kelas ini telah tercapai. Hasil penelitian secara umum adalah sebagai berikut:

1. Data awal pada bulan Januari, kemampuan matematika semua siswa mendapat nilai di bawah 75. Pada siklus 1, hanya ada seorang siswa yang lulus, kemudian setelah siklus 2 semua siswa mencapai nilai di atas standar ketuntasan minimal yang ditetapkan.

2. Data saat observasi awal, nilai karakter setiap siswa sangat rendah dengan rincian percaya diri 2.5 , toleransi 2.18 , kreatif 2.33 , komunikasi 2.33, dan kerjasama 2.33. Setelah siklus 1, nilai karakter siswa relatif meningkat dengan rata-rata tiap karakter sudah mencapai nilai 3 dengan rincian percaya diri 3.1, toleransi 3.3, kreatif 3.2, komunikasi 3.2, dan kerjasama 3.2. Namun rata-rata nilai karakter individu masih ada yang belum mencapai nilai 3 yaitu 2.9. Setelah siklus 2, rata-rata tiap karakter nilai sudah mencapai nilai 3 dengan rincian percaya diri 3.3, toleransi 3.6, kreatif 3.7, komunikasi 3.5, dan kerjasama 3.7. Ratarata nilai karakter tiap individu juga telah melampaui nilai 3 .

Dari semua data pendukung pembuktian pencapaian tujuan pembelajaran dapat disampaikan bahwa model Problem Based Learning (PBL) dengan pendekatan Realistic Mathematic dapat memberi jawaban yang diharapkan sesuai dengan tujuan penelitian ini. Semua ini dapat dicapai melalui kesiapan dan kerja keras, evaluasi bersama guru kelas, penyusunan instrumen penelitian, serta pelaksanaan penelitian yang maksimal. 
Graphing at an Indonesian Junior High School. Journal of Science and Mathematics Education in Southeast Asia, 2003, Vol. 26, No 2, pp. 1-51. 1

Abdullah, Nandiyah. (2013). Mengenal Anak Berkebutuhan Khusus. Jurnal Magistra No. 86 Th. XXV Desember 2013

Arikunto Suharsimi. (2006). Metodelogi Penelitian. Yogyakarta: Bina Aksara

Arikunto, Suharsimi; Suhardjono; Supardi. (2006). Penelitian Tindakan Kelas. Jakarta: PT Bumi Aksara.

Depdiknas. (2003). Undang-undang RI No.20 tahun 2003 tentang sistem pendidikan nasional.

Direktorat Pendidikan Luar Biasa. (2004). Pedoman Umum Penyelenggaraan Pendidikan Inklusif. Jakarta: Dirjendikdasmen.

Efendi, M. (2006). Pengantar Psikopedagogik Anak Berkelainan, Jakarta: Bumi Aksara.

Hmelo-Silver, Cindy E. dan Barrows, Howard S. (2006). Goals and Strategies of a Problem-based Learning Facilitator. Interdisciplinary Journal of ProblemBased Learning Vol. 1, Issues 1, Article 4.

Koesoema, D.A. (2007). Pendidikan Karakter: Strategi Mendidik Anak di Zaman Global. Jakarta: Grasindo

Marzuki. (2013). Revitalisasi Pendidikan Agama di Sekolah dalam Pembangunan Karakter Bangsa di Masa Depan. Jurnal Pendidikan Karakter. 3 (1): 64-76.

Stepien, William dan Gallagher, Shelagh. (1993). Problem-based learning: As authentic as it gets. Educational Leadership Journal, Apr93, Vol. 50 Issue 7, p25, 4p, 4bw

Widjaja, Yenni B. dan Heck, André. (2003). How a Realistic Mathematics Education Approach and Microcomputer-Based Laboratory Worked in Lessons on 